\title{
A Highlight on Avian Toxoplasmosis: One Health Disease with a Special Reference to the Current Egyptian Situation
}

\author{
Wafaa A. Abd El-Ghany \\ Poultry Diseases Department, Faculty of Veterinary Medicine, Cairo University, Giza, Egypt \\ *Corresponding author's E-mail: wafaa.ghany@yahoo.com; (DORCID: 0000-0003-1686-3831
}

\begin{abstract}
This review article was developed to the infection of avian species with Toxoplasma gondii ( $T$. gondii), diagnosis, pet bird and human infection, and control methods with a special reference to the current status of infection among the Egyptian poultry farms and population. Toxoplasmosis is a zoonotic disease caused by a unicellular, protozoan parasite $T$. gondii. Different domesticated and wild animals, as well as birds can harbor $T$. gondii and may be a potential source of infection to humans. Avian species could be infected with $T$. gondii through the ingestion of contaminated food, soil, and water with oocysts shed in the excreta of infected animals, especially cats. Poor sanitation and hygienic conditions increase the risk of infection. Consumption of food or water, as well as undercooked poultry meat or meat products containing the oocysts of the parasite, are the main sources of human infection with $T$. gondi. Diagnosis of $T$. gondii in the infected host depends on the serological detection of specific antibodies and molecular detection of the parasite. Microscopic demonstration of the oocysts and other developmental stages of the parasite in the intestine, liver, brain, and skeletal muscles tissues is another means for rapid diagnosis. Generally, a high prevalence of the disease is also reported in pet birds. Toxoplasmosis in humans is associated with abortion, congenital disorders, stillbirth, and other complications, especially in immunocompromised patients. Application of hygienic measures, as well as public awareness, are essential for the prevention and control of toxoplasmosis. In different Egyptian governorates, a high prevalence of $T$. gondii has been detected in animals, birds, and humans. High incidence of infection was recorded due to the contact with Toxoplasma oocysts shed mainly from infected cats or other carriers. Egyptian chicken and turkey flocks and backyard birds revealed the presence of different developmental stages of the parasite and even its antibodies. In addition, human populations showed signs of toxoplasmosis with severe complications.
\end{abstract}

Keywords: Bird, Egypt, Human, Toxoplasma gondii, Zoonosis

\section{INTRODUCTION}

Toxoplasmosis is an important zoonotic parasitic disease of public health importance (CDC, 2004) and it is caused by an obligatory intracellular protozoan parasite, Toxoplasma gondii (T. gondii) (Tenter et al., 2000). The disease is of widespread nature and causes significant economic and reproductive losses in animals and serious public health problems in humans (Sukthana, 2006; Pan et al., 2017). Toxoplasmosis is a cosmopolitan zoonotic parasitic disease of nearly all warm-blooded mammals and birds. The infection rate with $T$. gondii in humans, animals, and birds is influenced by some epidemiological risk factors, such as age, sex, feeding pattern, and geographical distribution (Wilking et al., 2016; Zhang et al., 2016). Strains of $T$. gondii are transferred through continents mainly by stray cats and other animals, including migratory birds (Can et al., 2014). Most domestic and wild avian species showed infection with T. gondii (Ammar et al., 2020; Mikaeel and Al-Saeed, 2020; Lv et al., 2021). Avian species become infected with $T$. gondii through ingestion of the infective oocysts contaminated soil, food, and water (Ruiz and Frenkel, 1980; Dubey et al., 2008) as these oocysts may be shed in the feces of host animal's like cats (Yan et al., 2009). The oocysts of the parasite were detected in the liver, brain, and muscles of broiler chickens (Deyab and Hassanein, 2005; Amin et al., 2012). On the other hand, humans get infected with $T$. gondii through ingestion of undercooked chicken meat containing infective oocysts or other stages of the parasite (Zhang et al., 2016). However, spontaneous abortion, mental, and congenital disorders, as well as stillbirth and other complications were observed in people infected with T. gondii (Krueger et al., 2014; Egorov et al., 2018). Generally, the diagnosis of toxoplasmosis depends mainly on the detection of specific antibodies using serological tests (Li et al., 2020). Microscopic examination and molecular techniques such as Polymerase Chain Reaction (PCR) are other methods used for the diagnosis of toxoplasmosis (Barakat et al., 2012; Ibrahim et al., 2016a).

Egyptian environment enhances the infection and transmission of $T$. gondii due to the presence abundant number of domestic or stray cats that shed oocysts and contaminate the environment. Animals such as sheep, goats, and chickens 
are regarded as important intermediate hosts for $T$. gondii and their meat is the main source of the parasite to humans in case consumed unhygienically (El-Massey et al., 1990). Serological tests reveal the presence of T. gondii infections with a high prevalence rate either in animal or human populations. In addition, definitive diagnostic procedures of clinical cases with toxoplasmosis in Egypt are still required (Abbas et al., 2020). Regarding the infection of avian species with $T$. gondii, insufficient data are available. Therefore, this review article was developed to highlight the infection of avian species with $T$. gondii, diagnosis, pet birds and human infection, and control methods with a special reference to the current status of infection among the Egyptian poultry farms and population.

\section{The protozoon parasite}

There are three morphological stages of toxoplasmosis infection, namely an active multiplying tachyzoite stage, slowly multiplying semi-dormant bradyzoite stage in tissue cysts, and a sporozoite stage within oocysts that present in the environment (Ferguson, 2004; Al-Ammash et al., 2018). It has been reported that sporulated oocysts of Toxoplasma spp. can persist and survive in the environment for a long time and can infect all warm-blooded animals, birds, and humans (Frenkel, 2000; Sibley et al., 2009; Abdel-Shafy et al., 2015). Oocysts require 1 to 5 days to sporulate and become infective. Environmental conditions such as warm temperature or high humidity are essential for the survival of oocysts. It has been found that the incidence of toxoplasmosis is higher in humid tropical areas than in arctic areas (Meerburg and Kijlstra, 2009; Simon et al., 2013). Suitable environmental conditions, such as high temperature especially in spring, summer, and early autumn enhance the sporulation of $T$. gondii oocysts.

Genetic polymorphic classification of $T$. gondii strains is based on detection of three major clonal lineage types I, II, and III, additional lineage, and recombinant or atypical genotypes (Shwab et al., 2014; Lorenzi et al., 2016). Type II strains of T. gondii were common in Europe (Ajzenberg et al., 2002), while type II and III strains were detected in subSaharan and North Africa, the Middle East, and the Peninsula (Al-Kappany et al., 2010a; Dubey et al., 2010; Mercier et al., 2010). In addition, types I, II, and III of T. gondii and the recombinant strains were found in North and Central, and South America (Pena et al., 2008; Khan et al., 2011; Rajendran et al., 2012). In some Asian countries such as Iran, the three major clonal lineages of T. gondii were also detected (Zia-Ali et al., 2007; Chaichan et al., 2017).

\section{Susceptibility of avian species to toxoplasmosis}

Various domestic and farm animals, including birds, showed infection with T. gondii (Mose et al., 2016). Direct detection of $T$. gondii oocysts in the environment is difficult, so infected broiler chickens are regarded as an important indicator for severe environmental contamination and poor hygienic conditions in poultry farms (Dubey, 2010; Mahmood et al., 2014). World-wide infection of domestic avian species, such as chickens, turkeys, ducks, and pigeons, with T. gondii has been recorded and they are considered as important sources of humans' infection (Dubey, 2010; Guo et al., 2015).

The prevalence rate of T. gondii in backyard chickens was 65.1\% in Rio de Janeiro (da Silva et al., 2003), 64\% in Ghana (Dubey et al., 2008), 11.4\% in China (Yan et al., 2009), and 38.4\% in Ethiopia (Tilahun et al., 2013). In Iraq, Mohammed and Abdullah (2013) detected T. gondii in domestic chickens kept in the house in Sulaimania Province, while Mikaeel and Al-Saeed (2020) found a high prevalence rate of the parasite among free-range local chickens in Duhok Province, and this was indicative for heavy environmental contamination with the parasite. In the same context, some researchers indicated that the infection rate of $T$. gondii was more in free-range chickens when compared with cages reared birds in Nanjing region, China (Liu et al., 2017) and in Egypt (Ibrahim et al., 2009). Moreover, in Pakistan, it has been observed that domesticated chickens could harbor more $T$. gondii than broiler chickens kept in farms which may be attributed to frequent contact of domesticated birds with cats and ground feeding habits (Khan et al., 2020). Besides, broiler chickens kept in farms are reared under a controlled environment, have fast growth, and have low chances of contact with reservoir animals, such as cats (Krueger et al., 2014). The experimental challenge of turkeys with T. gondii was successful (Dubey et al., 1993b).

Some reports investigated the presence of toxoplasmosis in pigeons as well as their relation to public health (Dubey, 2002; Tsai et al., 2006). Free-flying birds such as pigeons may act as another reservoir or source of Toxoplasma infection for contact birds, animals, or humans (Biancifiori et al., 1986). Besides, successful experimental infection of pigeons with $T$. gondii has been conducted with induction of signs and death (Simitch et al., 1965).

Water fowls, including ducks and geese, are also susceptible to T. gondii infection. The first detection of fetal toxoplasmosis in domesticated ducks was in Argentina (Boehringer et al., 1962), then the disease was recorded worldwide in different countries (Zardi et al., 1967; Literák and Hejlícek, 1993; El-Massry et al., 2000). The prevalence's rates of $T$. gondii in ducks were recorded as 56\% in Italy (Zardi et al., 1967) and 6\% in Florida (Burridge et al., 1979), as well as 20\% (Chen et al., 1986), 32.19\% (Zhai et al., 1987), 23.33\% (Zhang, 1989), and 3.93\% (Lv, 1993) in China. Moreover, ToxoDB\#9 genotype (Chinese I strain) was found to be predominant in ducks (Including 115 duck muscle samples, Zou et al., 2017). In China, T. gondii has been detected molecularly and serologically either in ducks (Lv et al., 2021) or geese (Rong et al., 2014). 
Successful oral infection of bobwhite quails (Dubey et al., 1993b) and Japanese quails (Dubey et al., 1994) with 49 strain of $T$. gondii oocysts has been reported. From the previous studies, the oocysts were re-isolated from the brain, heart, and muscles of the inoculated quails, moreover, antibodies to T. gondii were detected in quails for 63 days postinfection (PI) using an agglutination test. Experimental inoculation of quails with T. gondii tachyzoites revealed distribution and presence of this stage in the liver, lungs, and spleen at the day 7 PI, while the oocysts were detected in the brain and the heart of the birds on day 70 PI (Albuquerque et al., 2001).

Antibodies against $T$. gondii have been demonstrated serologically in ostriches in different localities of the world like Ghana (Dubey et al., 2000), Spain (Martínez-Díaz et al., 2002), Zimbabwe (Hove and Mukaratirwa, 2005), Brazil (Contente et al., 2009) and Egypt (El-Madawy and Metawea, 2013).

Wild birds are regarded as an important source and a reservoir for $T$. gondii for carnivores, besides, some of these birds are migratory and can spread the parasite worldwide (Nardoni et al., 2019). For instance, the prevalence rates of the parasite were $1 \%$ in doves, and $6.9 \%$ in the wild pigeon (Ammar et al., 2020), as well as $26.5 \%$ and $17.5 \%$ in sparrows of Iran (Khademvatan et al., 2013) and Brazil (Gondim et al., 2010), respectively. Moreover, the seroprevalences of $T$. gondii in broiler and layer chickens, pigeons, and sparrows using a random-effect model in Iran were $20 \%, 8 \%$, and $15 \%$, respectively (Shokri et al., 2017). In the same context, Amouei et al. (2018) serologically detected T. gondii in $51.4 \%$ of 385 free-ranging birds (chicken, ducks, and geese) and migratory birds (Anas crecca, Anas platyrhynchos, and Fulica atra).

Regarding the age's susceptibility, it has been reported that older hens were more susceptible to T. gondii than younger ones in the Thika Region of Kenya (Mose et al., 2016). A recent study by Lv et al. (2021) in China showed that ducks older than one year were more susceptible to the parasite than ducks younger than one year old.

\section{Pathogenicity of parasite}

Infection with $T$. gondii is mainly induced lesions in the liver and small intestine. The lesions are represented as congestion of the blood vessels and degenerative changes of the tissues. Congestion of the blood vessels is related to the ability of the parasite to pass from the intestine to the bloodstream and release some protein substances that destruct the blood platelets leading to increased vascular permeability and hemorrhages (Burney et al., 1999). The hyperplasia of the liver and the small intestine's cells were also reported (Amin et al., 2012). Infiltration of the parasite in the intestinal cells leads to apoptosis and deaths of some cells, while other cells show rapid regeneration and hyperplasia (Liesenfeld, 2002).

\section{Diagnosis of toxoplasmosis}

Rapid detection of the stages of $T$. gondii infection in avian hosts can be carried out through finding the parasites in stained impression smears or through histopathological sections of the affected organs (Dubey et al., 2007a; Dubey et al., 2007b; Ibrahim et al., 2016a). Moreover, T. gondii antigen could be detected using immunohistochemical staining techniques with polyclonal rabbit antibodies (Dubey et al., 2001). Intraperitoneal mouse inoculation (mouse bioassay) of T. gondii positive tissues should be done to obtain the tachyzoites stage (Dubey, 2010).

Diagnosis of $T$. gondii infection especially in birds is mainly based on the detection of specific antibodies using serological tests (Cabezón et al., 2011; Li et al., 2020). It has been reported that antibodies to Toxoplasma infection in cats could be detected within 3 weeks of infection and persisted in high titers for 5 years even in the absence of reinfection (Dubey, 1995). Enzyme-linked immunosorbent assay (ELISA), competitive-inhibition ELISA, indirect fluorescent antibody test (Nardoni et al., 2019), modified agglutination test (MAT) (Dubey, 2010; Alvarado-Esquivel et al., 2012; Rong et al., 2014), latex agglutination test (Raafat et al., 2011), Sabin-Feldman dye test (Literák and Hejlícek, 1993) and Western blotting are commonly used as serological techniques for the diagnosis of the disease (Huang et al., 2004). The most useful and commonly used serological test for the detection of $T$. gondii infection is MAT as it is specific, sensitive, does not require special equipment, and can be used for all avian species (Dubey, 2002). Tachyzoites of $T$. gondii could be maintained on monkey kidney adherent fibroblasts (Vero cells) cultures supplemented with $8 \%$ heat-inactivated fetal bovine serum for further serological detection (Ibrahim et al., 2016a).

The seroprevalences of $T$. gondii in domestic birds vary from one country to another according to the method used in testing, the number of the examined birds, and the type and the hygiene of breeding (Dubey, 2010). Many factor such as the locality, the number of birds, and the type and the hygiene of breeding affect the incidence or seroprevalences of T. gondii in domestic avian species (Dubey, 2010). For example, the seroprevalence of $T$. gondii antibodies among freeranging chickens was $27.1 \%$ in Southern Iran (Asgari et al., 2008) and 40.4\% in Giza Province of Egypt (Dubey et al., 2003a),

The molecular techniques for the diagnosis of $T$. gondii infection are based on the identification of immunodominant antigens using sera of animals infected with geographically distant isolates and from acute and chronically infected animals. In this regard, the surface antigen 2 of $T$. gondii (TgSAG2) which is expressed in Escherichia coli or the insect cells can be used as a useful, highly sensitive, and specific antigen for ELISA (Huang et 
al., 2002). Moreover, PCR is a specific, rapid, sensitive, and cost-effective technique that could be used for the detection of T. gondii DNA in chickens (Barakat et al., 2012). Howe et al. (1997) and Dubey et al. (2005) a fragment of 94 bp from the B1 gene of the parasite as a target to PCR amplification.

\section{Toxoplasmosis in pet birds}

Pet birds are usually kept in close contact with a human for companionship and entertainment. These birds play an important epidemiological role in the transmission and maintenance of many pathogens with public health significance for humans. Pet birds are bred in a semi-free-range system, so the birds have opportunities to contact food or water contaminated with $T$. gondii when they gather together. In addition, wild pet birds could transmit the protozoon in a long distance during flying and migration, and this transmission accelerated the spread of $T$. gondii diffusion. The role of pet birds in the transmission of $T$. gondii should be given more concern because they can serve as an important source of infection for cats (Ruiz and Frenkel, 1980; Dubey and Hamir, 2002). For instance, dead T. gondii infected pet birds from parks, pet shops or households are often un-hygienically disposed of and may be eaten by cats, and consequently, cats may become infected with the parasite and shed millions of oocysts. However, the transmission of T. gondii from pet birds to humans is not common as they are not bred for meat production (Boseret et al., 2013).

Up to now, some studies have been carried out to investigate the prevalence of $T$. gondii in psittacines and passerines species (Dubey, 2002; Hartley et al., 2008; Gazzonis et al., 2021). Fetal toxoplasmosis has been reported in parrots in Australia and New Zealand, psittacines in America, and budgerigars in Switzerland and the Netherlands (Dubey et al., 2004; Ferreira et al., 2012; Howe et al., 2014). In Brazil, the anti-T. gondii antibodies (IgY) were found in the serum of 71 adult blue-fronted Amazon parrots with a seropositivity rate of 9.8\% (Marietto-Gonçalves et al., 2013). Besides, Andrade et al. (2016) serologically examined 67 different psittacine species and found anti-T. gondii antibodies in $1.3 \%$ of the examined birds. However, the recent investigation of Sato et al. (2020) revealed the absence of antibodies against $T$. gondii in wild red-tailed Amazon parrots. For the first time in China, the anti- $T$. gondii antibodies were found in $13.63 \%$ of Cockatiels and 3.85\% of Lovebirds (Zhang et al., 2014). Further Chinese study of Cong et al. (2014) demonstrated that the seroprevalences of $T$. gondii were $11.65 \%, 11.39 \%$, and $5.26 \%$ in Eurasian Siskin, Oriental Skylark, and Black-tailed Grosbeak, respectively, and these birds molecularly showed the presence of T. gondii B1 gene and type II variant (ToxoDB genotype \#3). A virulent type II T. gondii strain has been isolated from a black-winged lory in North America (Dubey et al., 2004; Dubey et al., 2011), while type I/III variant $T$. gondii strain was demonstrated in Valley quail in Brazil (Casagrande et al., 2015). In Australia, based on histopathology, immunohistochemistry, and multilocus DNA typing findings, atypical type II genotype $T$. gondii strain was found in a pet peach-faced lovebird with nervous signs and lesions in the brain, spleen, liver, and heart (Cooper et al., 2015). Budgerigars are relatively resistant to clinical toxoplasmosis (Dubey and Hamir, 2002; Zhang et al., 2014). However, successful experimental infection of Budgerigars with $T$. gondii has been carried out (Kajerová et al., 2003). Before the identification of Toxoplasma species in 1908, the Toxoplasma-like parasite was detected in Java sparrows in the 1900s (Tenter et al., 2000), however, antibodies against $T$. gondii were detected in $34.29 \%$ of Java sparrows (Huang et al., 2019).

\section{Toxoplasmosis in human}

Recently, there is increasing attention to understand the main sources for human infection with toxoplasmosis (Dubey et al., 2008). Humans could be infected with T. gondii through ingestion of contaminated water or consumption of undercooked or raw poultry meat products containing infective oocysts or other stages of the parasite (Dubey and Jones, 2008; Dubey et al., 2010; Zhang et al., 2016). In addition, other problems such as congenital infection as well as blood transfusions and organs transplantation transmission methods have been reported (Tenter et al., 2000). Several factors are associated with infection of humans with $T$. gondii such as food handling and preparation hygiene, eating habits, levels of natural immunity, the oocysts contamination of the environment, and the level of contact with infected animals (del-Castillo and Herruzo, 1998; Swai and Schoonman, 2009).

It has been estimated that one-third of humans could be infected by T. gondii (Shokri et al., 2017) leading to different mental and congenital disorders, spontaneous abortion, and stillbirth (Krueger et al., 2014). In the United State of America, about 400-4000 infants are born with congenital toxoplasmosis having some complications like schizophrenia and obsessive-compulsive disorder (Egorov et al., 2018).

Toxoplasmosis is not commonly a significant problem for healthy people, however, it can be a life-threatening problem for congenitally infected young immuno-deficient patients, and primary infected pregnant women resulting in an acute or reactivated infection or even death (Pinard et al., 2003; Montoya and Liesenfeld, 2004; Remington et al., 2006). In Pakistan, the reports showed that the prevalence of $T$. gondii in the human population ranged from $12 \%$ to $28 \%$ (Majid et al., 2016; Latif et al., 2017; Nazir et al., 2017).

\section{Toxoplasmosis in Egypt}


Identification of $T$. gondii infections either in humans, animals, and birds in Egypt is commonly based on serological and molecular techniques. The high prevalence of $T$. gondii infection in Egypt may be related to the presence of an abundant number of homeless cats that live on scraps of garbage to hunt for their food (Abbas et al., 2020). These cats are the main host and source of the parasite that heavily contaminate the environment with oocysts. Animals and birds can get the infection with $T$. gondii from this contaminated environment (Al-Kappany et al., 2010b). The main risk factor associated with $T$. gondii seropositive free-range and wild birds may be the contact with soil-harboring oocysts from street cats (Ibrahim et al., 2009). The high seroprevalence rate of $T$. gondii in free-range and cage chickens may be owing to the contact with soil-harboring oocysts shed from street cats (Ibrahim et al., 2009). Consumption of improperly cooked or grilled meat and meat products of domesticated animals (rabbits and poultry) is a major risk factor for Egyptians, especially those living in rural areas (Abou Elez et al., 2017).

From 2000 until 2020, the seroprevalences of T. gondii in birds were variable in different provinces of Egypt based on the geographical location, type of the collected samples, season, and the bird's species, age, and sex. Table 1 shows the incidences and the prevalence rates of $T$. gondii infections in different avian species from different provinces in Egypt in the period from 2000-2020.

Table 1. The incidences and the prevalence rates of Toxoplasma gondii infections in different avian species from different provinces in Egypt in the period from 2000-2020.

\begin{tabular}{|c|c|c|}
\hline Species of birds & The findings & References \\
\hline $\begin{array}{l}\text { Commercial } \\
\text { turkeys, chickens, } \\
\text { and ducks }\end{array}$ & $\begin{array}{l}\text { The MAT has been done to detect the presence of antibodies against } T \text {. gondii in the sera of } 173 \\
\text { turkeys, } 108 \text { chickens, and } 48 \text { ducks from Giza, Egypt. The prevalence rateS of anti-T. gondii } \\
\text { antibodies among turkeys, chickens, and ducks were } 59.5 \%, 47.2 \% \text {, and } 50 \% \text {, respectively. }\end{array}$ & El-Massry et al. (2000) \\
\hline $\begin{array}{l}\text { Commercial } \\
\text { chickens }\end{array}$ & $\begin{array}{l}\text { A high prevalence rate }(40.4 \%) \text { of } T . \text { gondii in chickens from the rural area surrounding Giza } \\
\text { (South of Cairo), Egypt was detected using MAT. }\end{array}$ & Dubey et al. (2003) \\
\hline $\begin{array}{l}\text { House-bred and } \\
\text { farm-bred chickens }\end{array}$ & $\begin{array}{l}\text { The seroprevalence of Toxoplasma antibodies was } 30.0 \% \text { (18 out of } 60) \text { in house-bred chickens, } \\
\text { while it was } 11.1 \% \text { ( } 10 \text { out of } 90) \text { in farm-bred chickens by MAT in different Egyptian } \\
\text { governorates. The histopathological examination of the tissues revealed lesions induced by } T \text {. } \\
\text { gondii and the oocysts were detected in the liver, brain, heart, and skeletal muscles of } 22(78.6 \%) \\
\text { out of } 28 \text { positive chickens. }\end{array}$ & $\begin{array}{l}\text { Deyab and Hassanein } \\
(2005)\end{array}$ \\
\hline $\begin{array}{l}\text { Free-range and } \\
\text { caged chickens }\end{array}$ & $\begin{array}{l}\text { Serological detection of } T \text {. gondii specific antibodies, as well as tissue oocysts, showed positive } \\
\text { percentages of } 16.49 \text { and } 11.34 \% \text { in the free-range chickens and } 8.69 \text { and } 4.83 \% \text { in the caged } \\
\text { chickens, respectively in Delta provinces, Egypt. }\end{array}$ & Ibrahim et al. (2009) \\
\hline Ducks & $\begin{array}{l}\text { The prevalence of } T \text {. gondii was detected in ducks from Behera governorate, Egypt using MAT. } \\
\text { The prevalence rate of the parasite was } 13.9 \% \text {. The highest prevalence was in the native breed } \\
(17.65 \%) \text { and the } 6-8 \text {-months age group }(19.4 \%) \text {. }\end{array}$ & AbouLaila et al. (2011) \\
\hline Quails & $\begin{array}{l}\text { The presence of anti- } T \text {. gondii antibodies in the fecal and serum samples of native quails in Giza } \\
\text { province, Egypt has been detected. It has been found that } T \text {. gondii antibodies prevalence rates } \\
\text { were } 29.8 \text { and } 25.5 \% \text {, using MAT and LAT, respectively. }\end{array}$ & Raafat et al. (2011) \\
\hline $\begin{array}{l}\text { Free-range and } \\
\text { commercial } \\
\text { chickens }\end{array}$ & $\begin{array}{l}\text { The seroprevalence rates of } T \text {. gondii in chickens of six Egyptian governorates were compared } \\
\text { using ELISA. In addition, the presence of local T. gondii chicken strain was confirmed by PCR. } \\
\text { The total prevalence rate was } 68.8 \% \text { comprised of } 59.5 \%, 82.3 \%, 67.1 \%, 62.2 \%, 75 \% \text {, and } 50 \% \\
\text { in El Sharkia, El Gharbia, Kafr El sheikh, Cairo, Quena, and Sohag governorates, respectively. } \\
\text { Moreover, the prevalence rates were higher among free-range }(69.5 \%) \text { than commercial farm } \\
\text { chickens ( } 68.5 \%) \text {; while the prevalence rate was less in upper Egypt than lower Egypt } \\
\text { governorates and Cairo. }\end{array}$ & Barakat et al. (2012) \\
\hline $\begin{array}{l}\text { Free-range and } \\
\text { farmed chickens }\end{array}$ & $\begin{array}{l}\text { The seroprevalence of } T \text {. gondii infection in domestic chickens and humans in Beni-Suef } \\
\text { province, Egypt was demonstrated. Serum samples of } 215 \text { ( } 90 \text { free-range and } 125 \text { farmed) } \\
\text { chickens were examined using MAT. In addition, } 250 \text { sera samples were collected and examined } \\
\text { for IgG using ELISA. The results showed } 20 \% \text { and } 9.6 \% \text { of antibodies of } T \text {. gondii in free-range } \\
\text { and farmed chickens, respectively. However, antibodies to } T \text {. gondii were detected in } 37.5 \% \text { of } \\
\text { poultry contact workers and in } 30.5 \% \text { of non-poultry contacts persons. Seroprevalence of } 45.0 \\
\text { and } 41.66 \% \text { were observed among persons of ages } 41-50 \text { years and }>50 \text { years, respectively. }\end{array}$ & $\begin{array}{l}\text { Aboelhadid et al. } \\
\text { (2013) }\end{array}$ \\
\hline Chickens & $\begin{array}{l}\text { A total of } 304 \text { blood and brain samples were collected from chickens in the Delta provinces of } \\
\text { Egypt. The prevalence rates of } T \text {. gondii infection were } 11.18 \%, 6.91 \%, 6.91 \% \text { using ELISA, } \\
\text { histopathology, and immunohistochemistry methods, respectively. Moreover, significant } \\
\text { differences in the prevalence of } T \text {. gondii were detected on the basis of season, sex and habitat. }\end{array}$ & Ibrahim et al. (2016a) \\
\hline Ostriches & $\begin{array}{l}\text { One hundred and twenty serum samples from ostriches in Ismailia province, Egypt were tested } \\
\text { for anti- T. gondii antibodies using ELISA and MAT tests. Using enzyme immunoassay, } 5 \text { out of } \\
120 \text { birds }(4.2 \%) \text { were positive to IgM, while } 11 \text { birds }(9.2 \%) \text { were positive to IgG. However, } \\
\text { MAT detected IgG in } 15 \text { birds }(12.5 \%) \text {. The results of PCR revealed the presence of } T \text {. gondii } \\
\text { DNA in the blood of } 9 \text { birds }(7.5 \%) \text {. The results of PCR of the tissues showed positive T. gondii } \\
\text { DNA in } 5 \text { dead birds either in the heart, brain, and thigh muscles. }\end{array}$ & $\begin{array}{l}\text { El-Madawy and } \\
\text { Metawea (2013) }\end{array}$ \\
\hline Quails & $\begin{array}{l}\text { One hundred samples were collected from } 7-37 \text { days old diseased quails in Assiut and El-Menia } \\
\text { governorates, Egypt. The results of Giemsa-stained smears revealed the presence of } \\
\text { Toxoplasma's tachyzoites in } 7 \% \text { of the examined samples. }\end{array}$ & Hassan et al. (2020) \\
\hline
\end{tabular}


The seroprevalences of Toxoplasma infections in humans varied from $27 \%$ to $68 \%$ in asymptomatic pregnant women (Ghoneim et al., 2010; El Deeb et al., 2012; Ibrahim et al., 2016b), 26\% in cerebrospinal fluid of patients with meningoencephalitis (Mabrouk and Dahawi, 1991), and 59.6\% in blood donors without signs (Elsheikha et al., 2009). It has been reported a higher percentage of toxoplasmosis among Egyptians with liver cirrhosis (El-Henawy et al., 2015; El-Sayed et al., 2016). In the Province of Sharkia, Egypt, Mostafa et al. (2018) demonstrated a significant correlation between the seroprevalence of $T$. gondii in patients and the presence of different types of tumors as breast cancer, bone's squamous cell carcinoma, and brain tumors. Anti-Toxoplasma IgG was found in patients with liver tumors and bladder cancer, while IgM was detected in patients with benign uterine tumors, bone carcinoma, and breast cancer. In addition, $T$. gondii oocysts were detected in immuno-stained brain sections. In another study revealed a significantly higher proportion of seropositive anti-Toxoplasma IgG antibodies among type I diabetes mellitus patients (45\%) compared with the control group $(23.3 \%)$ (Khattab et al., 2019).

\section{Prevention and control of toxoplasmosis}

Estimation of zoonotic diseases in animals and birds is helpful for monitoring and improving public health in humans. Therefore, a definitive diagnosis of Toxoplasma infection in animals is necessary to prevent human zoonose infection (AbouLaila et al., 2011). Definitive diagnosis of zoonotic diseases with public health concerns, such as toxoplasmosis is very helpful for the prevention of human infection (AbouLaila et al., 2011).

Consumption of insufficiently cooked meat of birds should be avoided as well as fecal contamination from birds should be controlled (Raafat et al., 2011). Nardoni et al. (2019) demonstrated the wide distribution of T. gondii in game and wild birds and advised accurate estimation of the human infection risks in handling, managing, and eating wild bird species with regard to domestic carnivores and the impact of viscera or offal's in the environment.

Free-ranged and farmed chickens are regarded as a potential risk to the contact resident persons, so, application of strict preventive hygiene measures is a must to avoid transmission of $T$. gondii infection from birds to humans (Aboelhadid et al., 2013; Mikaeel and Al-Saeed, 2020).

It is very essential to implement a high level of education and awareness among populations to reduce the prevalence of toxoplasmosis (Jones et al., 2001). Consumption of undercooked animal products or unwashed raw vegetable/fruit, poor hands hygiene, and un-carful contact with soil, farm animals, and birds should be avoided (El Deeb et al., 2012). Furthermore, periodic exclusion diagnosis of toxoplasmosis in patients with chronic diseases should be done to avoid the possibility of increasing the disease's severity and for possible management of these malignancies.

\section{CONCLUSION}

Toxoplasmosis represents a complex problem, not only for animals and birds but also for human health, especially under Egyptian conditions. However, the current situation of avian toxoplasmosis in Egypt still needs more investigation. Therefore, periodical detection of toxoplasmosis prevalence's in living birds or in their products as well as application of hygienic measures in poultry farms are important to avoid the possibility of zoonotic transmission. In addition, periodical testing and examination, as well as public health awareness of human populations, are very critical.

\section{DECLARATIONS}

\section{Competing interests}

The author has not declared any conflict of interest.

\section{Ethical considerations}

Plagiarism, consent to publish, misconduct, data fabrication and/or falsification, double publication and/or submission, and redundancy have been checked by the author.

\section{REFERENCES}

Abbas I, Villena I, and Dubey J (2020). A review on toxoplasmosis in humans and animals from Egypt. Parasitology, 147(2): 135-159. DOI: https://www.doi.org/10.1017/s0031182019001367

Abdel-Shafy S, Shaapan RM, Abdelrahman KA, El-Namaky AH, Abo-Aziza FAM, and Zeina HAA (2015). Detection of Toxoplasma gondii Apicomplexa: Sarcocystidae in the brown dog tick Rhipicephalus sanguineus Acari: Ixodidae fed on infected rabbits. Research Journal of Parasitology, 10: 142-150. DOI: https://www.dx.doi.org/10.3923/jp.2015.142.150

Aboelhadid SM, Abdel-Ghany AE, Ibrahim MA, and Mahran HA (2013). Seroprevalence of Toxoplasma gondii infection in chickens and humans in Beni Suef, Egypt. Global Veterineria, 11: 139-144. Available at: https://www.idosi.org/gv/gv11(2)13/3.pdf

Abou Elez R, Hassanen E, Tolba H, and Elsohaby I (2017). Seroprevalence and risk factors associated with Toxoplasma gondii infection in domestic rabbits and humans. Veterinary Parasitology: Regional Studies and Reports, 8: 133-137. DOI: https://www.doi.org/10.1016/j.vprsr.2017.02.009 
AbouLaila M, El-Bahy N, Hilali M, Yokoyama N, and Igarashi I (2011). Serodiagnosis of Toxoplasma gondii in ducks from Behera governorate, Egypt. The Journal of protozoology Research, 21: https://obihiro.repo.nii.ac.jp/?action=repository_action_common_download\&item_id=14

Ajzenberg D, Cogné N, Paris L, Bessières MH, Thulliez P, Filisetti D, Pelloux H, Marty P, and Dardé ML (2002). Genotype of 86 Toxoplasma gondil isolates associated with human congenital toxoplasmosis, and correlation with clinical findings. Journal of Infectious Diseases, 186(5): 684-689. DOI: https://www.doi.org/10.1086/342663

Al-Ammash MSJ, Al-Shaibani KTM, and Al-Abodi HRJ (2018). Investigating the prevalence of infection with Toxoplasma gondii in men and women in Samaraa city, Iraq. Plant Archives, 18(2): 2501-2508. Available at: http://www.plantarchives.org/18-

Albuquerque GR, Munhoz AD, Oliveira FCR, and Lopes CWG (2001). Biological behavior of P and Sero-47 strain of Toxoplasma gondii in an experimental infection in Japanese quail. British Journal of Veterinary Parasitology, 10: 55-59. Available at: http://rbpv.org.br/download/1022001/c10255 59

Al-Kappany YM, Rajendran C, Abu-Elwafa SA, Hilali M, Su C, and Dubey JP (2010a). Genetic diversity of Toxoplasma gondii isolates in Egyptian feral cats reveals new genotypes. Journal of Parasitology, 96(6): 1112-1114. DOI: https://www.doi.org/10.1645/ge-2608.1

Al-Kappany YM, Rajendran C, Ferreira LR, Kwok OC, Abu-Elwafa SA, Hilali M, and Dubey JP (2010b). High prevalence of toxoplasmosis in cats from Egypt: Isolation of viable Toxoplasma gondii, tissue distribution, and isolate designation. Journal of Parasitology, 96: 1115-1118. DOI: https://www.doi.org/10.1645/ge-2554.1

Alvarado-Esquivel C, González-Salazar AM, Alvarado-Esquivel D, OntiverosVázquez F, Vitela-Corrales J, Villena I, and Dubey JP (2012). Seroprevalence of Toxoplasma gondii infection in chickens in Durango State, Mexico. Journal of Parasitology, 98(2): 431-432. DOI https://www.doi.org/10.1645/ge-2979.1

Amin D, GholamReza H, Koorosh S, and Mohammad M (2012). Clinical, serological and histopathological signs of toxoplasmosis in broiler chicken (Gallus domesticus) after experimental infection. Comparative Clinical Pathology, 21: 1379-1382. DOI: https://www.doi.org/10.1007/s00580011-1300-X

Ammar S, Purple K, and Gerhold R (2020). Toxoplasma gondii prevalence in hunter-killed mourning doves (Zenaida macroura) and rock pigeons (Columba livia) from East Tennessee. Journal of Wildlife Diseases, 56: 479-481. DOI: https://www.doi.org/10.7589/2019-06-155

Amouei A, Sharif M, Hosseini SA, Sarvi S, Mizani A, Salehi S, Gholami S, Jafar-Ramaji T, and Daryani A (2018). Prevalence of Toxoplasma gondi infection in domestic and migrating birds from Mazandaran province, northern Iran. Avian Biology Research, 11(1): 12-15. DOI: https://www.doi.org/10.3184\%2F175815617X15105842200290

Andrade LHM, Lugarini C, Oliveira RAS, Silva LTR, Marvullo MFV, Garcia JE, Dubey JP, and Silva JCR (2016). Occurrence of antibodies to toxoplasma gondii in wild birds from three federal conservation units in Paraíba and Bahia / Occurrence of antibodies to toxoplasma gondii in wild birds from three federal conservation units in Paraíba and Bahia, Brazil. The Brazilian Journal of Veterinary Parasitology, 36(2): 103-107. DOI: http://www.dx.doi.org/10.1590/S0100-736X2016000200007

Asgari Q, Akrami Mohajeri F, Kalantari M, Esmaeilzadeh B, Farzaneh A, Moazeni M, Ghalebi SR, Saremi F, Zarifi Kalyani M, and Motazedian MH (2008). Chicken toxoplasmosis in different types of breeding: A seroprevalence survey in Southern Iran. International Journal of Poultry Science, 7: 1247-1250. DOI: https://www.dx.doi.org/10.3923/ijps.2008.1247.1250

Barakat AM, Salem LM, El-Newishy AM, Shaapan RM, and El-Mahllawy EKZ (2012). Zoonotic chicken toxoplasmosis in some Egyptians governorates. Pakistan Journal of Biological Sciences, 15: 821-826. DOI: https://www.dx.doi.org/10.3923/pjbs.2012.821.826

Biancifiori F, Rondini C, Grelloni V, and Frescura T (1986). Avian toxoplasmosis: Experimental infection of chicken and pigeon. Comparative Immunology, Microbiology and Infectious Diseases, 9(4): 337-346. DOI: https://www.doi.org/10.1016/0147-9571(86)90046-9

Boehringer EG, Fornari OE, and Boehringer OK (1962). The first case of fatal toxoplasmosis in domestic ducks in Argentina. Avian Diseases, 6(4): 391-396. DOI: https://www.doi.org/10.2307/1587913

Boseret G, Losson B, Mainil JG, Thiry E, and Saegerman C (2013). Zoonoses in pet birds: Review and perspectives. Veterinary Research, 44: 36. DOI: https://www.doi.org/10.1186/1297-9716-44-36

Burney DP, Lappin MR, and Spiker M (1999). Detection of Toxoplasma gondii parasitemia in experimentally inoculated cats. Journal of Parasitology, 65(5): 947-951. Available at: https://pubmed.ncbi.nlm.nih.gov/10577732/

Burridge MJ, Bigler WJ, Forrester DJ, and Hennemann JM (1979). Serologic survey for Toxoplasma gondii in wild animals in Florida. Journal of the American Veterinary Medical Association, 175: 964-967. Available at: https://pubmed.ncbi.nlm.nih.gov/521384/

Cabezón O, García-Bocanegra I, Molina-López R, Marco I, Blanco JM, Höfle U, Margalida A, Bach-Raich E, Darwich L, Echeverría I et al. (2011). Seropositivity and risk factors associated with Toxoplasma gondii infection in wild birds from Spain. PLoS One, 6(12): e29549. DOI https://www.doi.org/10.1371/journal.pone.0029549

Can H, Döşkaya M, Ajzenberg D, Özdemir HG, Caner A, İz SG, Döşkaya AD, Atalay E, Çetinkaya Ç, Ürgen S et al. (2014). Genetic characterization of Toxoplasma gondii isolates and toxoplasmosis seroprevalence in stray cats of İzmir, Turkey. PLoS One, 9(8): e104930. DOI: https://www.doi.org/10.1371/journal.pone.0104930

Casagrande RA, Pena HF, Cabral AD, Rolim VM, de Oliveira LG, Boabaid FM, Wouters AT, Wouters F, Cruz CE, and Driemeier D (2015). Fatal systemic toxoplasmosis in Valley quail (Callipepla californica). International Journal for Parasitology: Parasites and Wildlife, 4(2):264-267. DOI: https://www.dx.doi.org/10.1016\%2Fj.ijppaw.2015.04.003

Centers of Disease Control and Prevention (CDC) (2004). Toxoplasmosis. pp. 11-22. Available at: https://www.cdc.gov/parasites/toxoplasmosis/index.html

Chaichan P, Mercier A, Galal L, Mahittikorn A, Ariey F, Morand S, Boumédiène F, Udonsom R, Hamidovic A, Murat JB et al. (2017). Geographical distribution of Toxoplasma gondii genotypes in Asia: A link with neighboring continents. Infection, Genetics and Evolution, 53: 227-238. DOI: https://www.doi.org/10.1016/j.meegid.2017.06.002

Chen GL, Zhang RT, Xu YW, and Ma JH (1986). A preliminary report for antibodies to Toxoplasma gondii in domestic livestock in Changchun area. Journal of Veterinary College, University of PLA, 6: 66-67. Available at: https://europepmc.org/article/MED/20707861

Cong W, Meng QF, Song HQ, Zhou DH, Huang SY, Qian AD, Su C, and Zhu XQ (2014). Seroprevalence and genetic characterization of Toxoplasma gondii in three species of pet birds in China. Parasites Vectors, 7: 152. DOI: https://www.doi.org/10.1186/1756-3305-7-152

Contente APA, Domingues PF, and Silva RC (2009). Prevalence of T. gondii antibodies in-ostriches (Struthio camelus) from commercial breeding facilities in the state of São Paulo, Brazil. Brasilian Journal of Veterinary Research and Animal Science, 46(3): 175-180. DOI: https://www.doi.org/10.11606/issn.1678-4456.bjvras.2009.26764

Cooper MK, Šlapeta J, Donahoe SL, and Phalen DN (2015). Toxoplasmosis in a pet peach-faced lovebird (Agapornis roseicollis). Korean Journal of Parasitology, 53(6): 749-753. DOI: https://www.doi.org/10.3347/kjp.2015.53.6.749 
da Silva DS, Bahia-Oliveira LM, Shen S, Kwok OCH, Lehman T, and Dubey J (2003). Prevalence of Toxoplasma gondii in chickens from an area in southern Brazil highly endemic to humans. Journal of Parasitology, 89: 394-396. DOI: https://www.doi.org/10.1645/0022-

Del-Castillo F, and Herruzo R (1998). Risk factors for toxoplasmosis in children. Enfermedades Infecciosas y Microbiologia Clinica, 16: 224-222. Available at: https://pubmed.ncbi.nlm.nih.gov/9666585/

Deyab AK, and Hassanein R (2005). Zoonotic toxoplasmosis in chicken. Journal of the Egyptian Society of Parasitology, 35: 341-350. Available at: https://pubmed.ncbi.nlm.nih.gov/15881017/

Dubey JP (1995). Duration of immunity to shedding of Toxoplasma gondii oocysts by cats. Journal of Parasitology, 81(3): 410-415. DOI: https://www.doi.org/10.2307/3283823

Dubey JP (2002). A review of toxoplamosis in wild birds. Veterinary Parasitology, 106(2): 121-153. DOI: https://www.doi.org/10.1016/s03044017(02)00034-1

Dubey JP (2010). Toxoplasma gondii infections in chickens Gallus domesticus: Prevalence, clinical disease, diagnosis and public health significance. Zoonoses Public Health, 57: 60-73. DOI: https://www.doi.org/10.1111/j.1863-2378.2009.01274.X

Dubey JP, and Hamir AN (2002). Experimental toxoplasmosis in budgerigars (Melopsittacus undulatus). Journal of Parasitology, 88: 514-519. DOI: https://www.doi.org/10.1645/0022-3395(2002)088[0514:etibmu]2.0.co;2

Dubey JP, and Jones JL (2008). Toxoplasma gondii infection in humans and animals in the United States. International Journal of Parasitology, 38(11): 1257-1278. DOI: https://www.doi.org/10.1016/j.ijpara.2008.03.007

Dubey JP, Camargo ME, Ruff MD, Shen SK, Wilkins GL, Kwok OCH, and Thulliez P (1993a). Experimental toxoplasmosis in turkeys. Journal of Parasitology, 79(6): 949-952. DOI: https://www.doi.org/10.2307/3283736

Dubey JP, Ruff MD, Camargo ME, Shen SK, Kwok OCH, Wilkins GL, and Thulliez P (1993b). Experimental toxoplasmosis in Bob-white quail (Colinus virginianus). Journal of Parasitology, 79(6): 935-939. DOI: https://www.doi.org/10.2307/3283733

Dubey JP, Goodwin MA, Ruff MD, Kwok OCH, Shen SK, Wilkins GL, and Thulliez P (1994). Experimental toxoplasmosis in Japanese quail. Journal of Veterinary Diagnostic Investigation, 6(2): 216-221. DOI: https://www.doi.org/10.1177\%2F104063879400600213

Dubey JP, Scandrett WB, Kwok OCH, and Gajadhar AA (2000). Prevalence of antibodies to T. gondii in ostriches Struthio camelus). Journal of Parasitology, 86(3): 623-624. DOI: https://www.doi.org/10.1645/0022-3395(2000)086[0623:poattg]2.0.co;2

Dubey JP, Garner MM, Willette MM, Batey KL, and Gardiner CH (2001). Disseminated toxoplasmosis in magpie geese (Anseranas sempalmata) with large numbers of tissue cysts in livers. Journal of Parasitology, 87(1): 219-223. DOI: https://www.doi.org/10.1645/0022-

Dubey JP, Graham DH, Dahl E, Hilali M, El-Ghaysh A, Sreekumar C, Kwok OC, Shen SK, and Lehmann T (2003). Isolation and molecular characterization of Toxoplasma gondii from chickens and ducks from Egypt. Veterinary Parasitology, 114(2): 89-95. DOI: https://www.doi.org/10.1016/s0304-4017(03)00133-X

Dubey JP, Parnell PG, Sreekumar C, Vianna MC, De Young RW, Dahl E, and Lehmann T (2004). Biologic and molecular characteristics of Toxoplasma gondii isolates from striped skunk (Mephitis mephitis), Canada goose (Branta canadensis), black-winged lory (Eos cyanogenia), and cats (Felis catus). Journal of Parasitology, 90(5): 1171-1174. DOI: https://www.doi.org/10.1645/ge-340r

Dubey JP, Lopez B, Alvarez M, Mendoza C, and Lehmann T (2005). Isolation, tissue distribution and molecular characterization of Toxoplasma gondii from free-range chickens from Guatemala. Journal of Parasitology, 91: 955-957. DOI: https://www.doi.org/10.1645/ge-493r.1

Dubey JP, Sundar N, Gennari SM, Minervino AH, Farias NA, Ruas JL, dos Santos TR, Cavalcante GT, Kwok OC, and Su C (2007a). Biologic and genetic comparison of Toxoplasma gondii isolates in free-range chickens from the northern Pará state and the southern state Rio Grande do

Sul, Brazil revealed highly diverse and distinct parasite populations. Veterinary Parasitology, 143(2): 182-188. DOI: https://www.doi.org/10.1016/j.vetpar.2006.08.024

Dubey JP, Webb DM, Sundar N, Velmurugan GV, Bandini LA, Kwok OCH, Su C (2007b). Endemic avian toxoplasmosis on a farm in Illinois: clinical disease, diagnosis, biologic and genetic characteristics of Toxoplasma gondii isolates from chickens (Gallus domesticus), and a goose (Anser anser). Veterinary Parasitology, 148: 207-212. DOI: https://www.doi.org/10.1016/j.vetpar.2007.06.033

Dubey JP, Huong LTT, Lawson BWL, Subekti DT, Tassi P, Cabaj W, Sundar N, Velmurugan GV, Kwok OC, and Su C (2008). Seroprevalence and isolation of Toxoplasma gondii from free-range chickens in Ghana, Indonesia, Italy, Poland, and Vietnam. Journal of Parasitology, 94(1): 68-71. DOI: https://www.doi.org/10.1645/ge-1362.1

Dubey JP, Pas A, Rajendran C, Kwok OC, Ferreira LR, Martins J, Hebel C, Hammer S, and Su C (2010). Toxoplasmosis in Sand cats (Felis margarita) and other animals in the breeding centre for endangered Arabian wildlife in the United Arab Emirates and Al Wabra wildlife preservation, the State of Qatar. Veterinary Parasitology, 172: 195-203. DOI: https://www.doi.org/10.1016/j.vetpar.2010.05.013

Dubey JP, Velmurugan GV, Rajendran C, Yabsley MJ, Thomas NJ, Beckmen KB, Sinnett D, Ruid D, Hart J, Fair PA et al. (2011). Genetic characterisation of Toxoplasma gondii in wildlife from North America revealed widespread and high prevalence of the fourth clonal type. International Journal of Parasitology, 41(11): 1139-1147. DOI: https://www.doi.org/10.1016/j.ijpara.2011.06.005

Egorov AI, Converse R, Griffin SM, Styles J, Klein E, Sams E, Hudgens E, and Wade TJ (2018). Environmental risk factors for Toxoplasma gondii infections and the impact of latent infections on allostatic load in residents of Central North Carolina. BMC Infectious Diseases, 18(1): 421. DOI: https://www.doi.org/10.1186/s12879-018-3343-y

El Deeb HK, Salah-Eldin H, Khodeer S, and Allah AA (2012). Prevalence of Toxoplasma gondii infection in antenatal population in Menoufia governorate, Egypt. Acta Tropica, 124(3): 185-191. DOI: https://www.doi.org/10.1016/j.actatropica.2012.08.005

El-Henawy A, Abdel-Razik A, Zakaria S, Elhammady D, Saudy N, and Azab MS (2015). Is toxoplasmosis a potential risk factor for liver cirrhosis? Asian Pacific Journal of Tropical Medicine, 8(10): 784-791. DOI: https://www.doi.org/10.1016/j.apjtm.2015.09.003

El-Madawy SR, and Metawea FY (2013). Serological assays and PCR for detection of Toxoplasma gondii infection in an ostrich farm at Ismailia Province, Egypt. IOSR Journal of Agriculture Veterinary Science, 2(3): 56-60. Available at: https://www.bu.edu.eg/portal/uploads/Veterinary\%20Medicine/Animal\%20Hygiene, $\% 20$

El-Massey AA, Abdel-Gawad AM, and Nassar AM (1990). Isolation of Toxoplasma gondii, Isospora felis and Isospora revolta from (sheep, goats, chicken) in Egypt. Journal of the Egyptian Veterinary Medical Association, 50: 275-284. Available at: https://scialert.net/fulltext/?doi=pjbs.2012.821.826\&org=11

El-Massry A, Mahdy OA, El-Ghaysh A, and Dubey JP (2000). Prevalence of Toxoplasma gondii antibodies in sera of turkeys, chickens, and ducks from Egypt. Journal of Parasitology, 86(3): 627-628. DOI: https://www.doi.org/10.1645/0022-3395(2000)086[0627:potgai]2.0.co;2

El-Sayed NM, Ramadan ME, and Ramadan ME (2016). Toxoplasma gondii infection and chronic liver diseases: Evidence of an association. Tropical Medicine and Infectious Diseases, 1(1): 7. DOI: https://www.dx.doi.org/10.3390\%2Ftropicalmed1010007

Elsheikha HM, Azab MS, Abousamra NK, Rahbar MH, Elghannam DM, and Raafat D (2009). Seroprevalence of and risk factors for Toxoplasma gondii antibodies among asymptomatic blood donors in Egypt. Parasitology Research, 104(6): 1471-1476. DOI: https://www.doi.org/10.1007/s00436-009-1350-Z 
Ferguson DJ (2004). Use of molecular and ultra-structural markers to evaluate stage conversion of Toxoplasma gondii in both the intermediate and definitive host. International Journal of Parasitology, 34: 347-360. DOI: https://www.doi.org/10.1016/j.ijpara.2003.11.024

Ferreira FC Jr, Donatti RV, Marques MV, Ecco R, Preis IS, Shivaprasad HL, Vilela DA, and Martins NR (2012). Fatal toxoplasmosis in a vinaceous Amazon parrot (Amazona vinacea). Avian Diseases, 56(4):774-777. DOI: https://www.doi.org/10.1637/10063-011912-case.1

Frenkel JK (2000). Biology of Toxoplasma gondii. In: Ambroise-Thomas P., Petersen P.E. (eds) Congenital toxoplasmosis. Springer, Paris, pp. 9-25. DOI: https://www.doi.org/10.1007/978-2-8178-0847-5_2

Gazzonis AL, Villa L, Lubian E, Ressegotti S, Grilli G, Raimondi S, Zanzani SA, and Manfredi MT (2021). Molecular survey on Toxoplasma gondii and Neospora caninum infection in wild birds of prey admitted to Recovery Centers in Northern Italy. Microorganisms, 9(4): 736. DOI: https://www.doi.org/10.3390/microorganisms9040736

Ghoneim NH, Shalaby SI, Hassanain NA, Zeedan GS, Soliman YA, and Abdalhamed AM (2010). Comparative study between serological and molecular methods for diagnosis of toxoplasmosis in women and small ruminants in Egypt. Foodborne Pathogens and Disease, 7(1): 17-22. DOI: https://www.doi.org/10.1089/fpd.2008.0223

Gondim LSQ, Abe-Sandes K, Uzêda RS, Silva MSA, Santos SL, Mota RA, Vilela SM, and Gondim LF (2010). Toxoplasma gondii and Neospora caninum in sparrows (Passer domesticus) in the Northeast of Brazil. Veterinary Parasitology, 168: 121-124. DOI: https://www.doi.org/10.1016/j.vetpar.2009.09.055

Guo M, Duney J, Tender P, Hill D, Buchanan RL, Gamble HR, Jones JL, and Pradhan AK (2015). Prevalence and risk factors for Toxoplasma gondii infection in meat animals and meat products destined for human consumption. Journal of Food Protection, 78(2): 457-476. DOI: https://www.doi.org/10.4315/0362-028x.jfp-14-328

Hartley J, Booth R, Slocombe RF, and Dubey JP (2008). Lethal toxoplasmosis in an aviary of kakarikis (Cyanoramphus spp.) in Australia. Journal of Parasitology, 94(6): 1424-1425. DOI: https://www.doi.org/10.1645/ge-1619.1

Hassan AK, Naeem EV, and Soliman MA (2020). Investigation the prevalence of common parasitic infections in farmed quails in Upper Egypt. SVUInternational Journal of Veterinary Sciences, 3(2): 38-50. DOI: https://www.dx.doi.org/10.21608/svu.2020.31915.1058

Hove T, and Mukaratirwa S (2005). Seroprevalence of T. gondii in farm-reared ostriches and wild game species from Zimbabwe, Acta Tropica, 94(1): 49-53. DOI: https://www.doi.org/10.1016/j.actatropica.2004.10.010

Howe DK, Honore S, Derouin F, and Sibley LD (1997). Determination of genotypes of Toxoplasma gondii strains isolated from patients with toxoplasmosis. Journal of Clinical Microbiology, 35(6): 1411-1414. Available at: https://www.ncbi.nlm.nih.gov/pubmed/9163454

Howe L, Hunter S, Burrows E, and Roe W (2014). Four cases of fatal toxoplasmosis in three species of endemic New Zealand birds. Avian Diseases, 58(1): 171-175. DOI: https://www.doi.org/10.1637/10625-080413-case.1

Huang X, Xuan X, Suzuki H, Sugimoto C, Nagasawa H, Fujisaki K, Mikami T, and Igarashi I (2002). Characterization of Toxoplasma gondii SAG2 expressed in insect cells by recombinant baculovirus and evaluation of its diagnostic potential in an enzyme-linked immunosorbent assay. Clinical and Diagnostic Laboratory Immunology, 9(6): 1343-1347. DOI: https://www.dx.doi.org/10.1128\%2FCDLI.9.6.1343-1347.2002

Huang X, Xuan X, Hirata H, Yokoyama N, Xu L, Suzuki N, and Igarashi I (2004). Rapid immunochromatographic test using recombinant SAG2 for detection of antibodies against Toxoplasma gondii in cats. Journal of Clinical Microbiology, 42(1): 351-353. DOI: https://www.dx.doi.org/10.1128\%2FJCM.42.1.351-353.2004

Huang SY, Fan YM, Chen K, Yao QX, and Yang B (2019). Seroprevalence and risk assessment of Toxoplasma gondii in Java sparrows (Lonchura oryzivora) in China. BMC Veterinary Research, 15: 129. DOI: https://www.doi.org/10.1186/s12917-019-1888-7

Ibrahim HM, Huang P, Salem TA, Talaat RM, Nasr MI, Xuan X, and Nishikawa Y (2009). Prevalence of Neospora caninum and Toxoplasma gondii antibodies in northern Egypt. American Journal of Tropical Medicine and Hygiene, 80(2): 263-267. DOI: https://www.doi.org/10.4269/ajtmh.2009.80.263

Ibrahim HM, Abdel-Ghaffar F, Osman GY, El-Shourbagy SH, Nishikawa Y, and Khattab RA (2016a). Prevalence of Toxoplasma gondii in chicken samples from delta of Egypt using ELISA, histopathology and immunohistochemistry. Journal of Parasitic Diseases, 40(2): 485-490. DOI: https://www.dx.doi.org/10.1007\%2Fs12639-014-0530-7

Ibrahim I, Salah H, El Sayed H, Mansour H, Eissa A, Wood J, Fathi W, Tobar S, Gur RC, Gur RE et al. (2016b). Hepatitis C virus antibody titers associated with cognitive dysfunction in an asymptomatic community-based sample. Journal of Clinical and Experimental Neuropsychology, 38: 861-868. DOI: https://www.doi.org/10.1080/13803395.2016.1168780

Jones JL, Kruszon-Moran D, Wilson M, McQuillan G, Navin T, and McAuley JB (2001). Toxoplasma gondii infection in the United States: seroprevalence and risk factors. American Journal of Epidemiology, 154(4): 357-365. DOI: https://www.doi.org/10.1093/aje/154.4.357

Kajerová V, Literák I, Bártová E, and Sedlák K (2003). Experimental infection of budgerigars (Melopsittacus undulatus) with a low virulent K21 strain of Toxoplasma gondii. Veterinary Parasitology, 116(4): 297-304. DOI: https://www.doi.org/10.1016/j.vetpar.2003.07.008

Khademvatan S, Saki J, Yousefi E, and Abdizadeh R (2013). Detection and genotyping of Toxoplasma gondii strains isolated from birds in the southwest of Iran. British Poultry Science, 54(1):76-80. DOI: https://www.doi.org/10.1080/00071668.2013.763899

Khan A, Dubey JP, Su C, SibleyL D, Ajioka JW, and Rosenthal BM (2011). Genetic analyses of atypical Toxoplasma gondii strains reveal a fourth clonal lineage in North America. International Journal of Parasitology, 41(6): 645-655. DOI: https://www.doi.org/10.1016/j.ijpara.2011.01.005

Khan MB, Khan S, Rafiq K, Khan SN, Attaullah S, and Ali I (2020). Molecular identification of Toxoplasma gondii in domesticated and broiler chickens (Gallus domesticus) that possibly augment the pool of human toxoplasmosis. PLoS One, 15(4): e0232026. DOI: https://www.doi.org/10.1371/journal.pone.0232026

Khattab HM, El Bassiouni SO, Abuelela MH, and Abd Elsalam DO (2018). Seroprevalence of Toxoplasma gondii among a group of Egyptian patients with type I diabetes mellitus. Bulletin of the National Research Centre, 43: 20. DOI: https://www.doi.org/10.1186/s42269-019-0059-0

Krueger WS, Hilborn ED, Converse RR, and Wade TJ (2014). Drinking water source and human Toxoplasma gondii infection in the United States: a cross sectional analysis of NHANCES data. BMC Public Health, 14: 711. DOI: https://www.doi.org/10.1186/1471-2458-14-711

Latif AA, Mushtaq S, Fazal S, Mansha M, and Yaqub A (2017). Seroprevalence of Toxoplasma gondii among pregnant women in Lahore, Pakistan. Biologia, 63(2): 141-146. Available at: https://www.semanticscholar.org/paper/Seroprevalence-of-Toxoplasma-gondii-among-

Li MH, Yang BT, Yin ZW, Wang W, Zhao Q, and Jiang J (2020). A seroepidemiological survey of Toxoplasma gondii and Chlamydia infection in chickens, ducks, and geese in Jilin province, northeastern China. Vector-Borne and Zoonotic Diseases, 20(11): 825-830. DOI: https://www.doi.org/10.1089/vbz.2020.2614

Liesenfeld O (2002). Oral infection of C57BL/6 mice with Toxoplasma gondii: A new model of inflammatory. Journal of Infectious Diseases, 185(1): 96-101. DOI: https://www.doi.org/10.1086/338006

Literák I, and Hejlícek K (1993). Incidence of Toxoplasma gondii in populations of domestic birds in the Czech republic. Avian Pathology, 22(2): 275281. DOI: https://www.doi.org/10.1080/03079459308418920 
Liu XC, He Y, Han DG, Zhang ZC, Li K, Wang S, Xu LX, Yan RF, and Li XR (2017). Detection of Toxoplasma gondii in chicken and soil of chicken farms in Nanjing region, China. Infectious Diseases of Poverty, 6(1): 62. DOI: https://www.doi.org/10.1186/s40249-017-0277-3

Lorenzi H, Khan A, Behnke MS, Namasivayam S, Swapna LS, Hadjithomas M, Karamycheva S, Pinney D, Brunk BP, Ajioka JW et al. (2016). Local admixture of amplified and diversified secreted pathogenesis determinants shapes mosaic Toxoplasma gondii genomes. Nature Communications, 7: 10147. DOI: https://www.doi.org/10.1038/ncomms10147

Lv YC (1993). A surveillance report of toxoplasmosis in domestic birds. Journal of Animal Health Inspection, 10: 31-32. Available at: https://pubag.nal.usda.gov/download/37140/PDF

Lv QY, Zheng HL, Yang WH, and Liu GH (2021). Molecular detection of Toxoplasma gondii and Neospora caninum in domestic ducks in Hunan province, China. Frontier in Veterinary Science, 8: 649603. DOI: https://www.doi.org/10.3389/fvets.2021.649603

Mabrouk MA, and Dahawi HS (1991). Toxoplasma antibodies in patients with meningoencephalitis. Journal of the Egyptian Society and Parasitology, 21(2): 547-551. Available at: https://pubmed.ncbi.nlm.nih.gov/1875079/

Majid A, Khan S, Jan AH, Taib M, Adnan M, Ali I, and Khan SN (2016). Chronic toxoplasmosis and possible risk factors associated with pregnant women in Khyber Pakhtunkhwa. Biotechnology and Biotechnological Equipment, 304: 733-736. DOI: https://www.doi.org/10.1080/13102818.2016.1175966

Mahmood Z, Zahid M, Sthanadar AA, Shah M, and Hussain A (2014). Seroprevalence of Toxoplasma gondii infection in Gallus domesticatedus of district Mardan, Khyber Pakhtunkhwa, Pakistan. Pakistan Journal of Zoology, 46(6): 1705-1710. Available at: https://www.zsp.com.pk/pdf46/1705-1710\%20(30)\%20PJZ-2007-14\%2024-9-

Marietto-Gonçalves GA, Almeida SM, Camossi LG, Langoni H, and Andreatti Filho RL (2013). Serological evaluation of Parainfluenzavirus Type 1, Salmonella spp., Mycoplasma spp., and Toxoplasma gondii in wild birds. A revista Ciência Animal Brasileira, 14(4): 473-480. DOI: http://www.dx.doi.org/10.5216/cab.v14i4.16576

Martínez-Díaz RA, Simmons B, and Ponee-Gordo F (2002). Serologic screening to detect T. gondii antibodies in farmed ostriches (Struthio camelus) in Spain. Revista Ibérica de Parasitología, $\quad 62:$ at: https://bibliotecavirtual.ranf.com/es/catalogo_imagenes/grupo.cmd?path=1001921

Meerburg BG, and Kijlstra A (2009). Changing climate-changing pathogens: Toxoplasma gondii in North-Western Europe. Parasitology Research, 105(1): 17-24. DOI: https://www.doi.org/10.1007/s00436-009-

Mercier A, Devillard S, Ngoubangoye B, Bonnabau H, Bañuls AL, Durand P, Salle B, Ajzenberg D, and Dardé ML (2010). Additional haplogroups of Toxoplasma gondii out of Africa: Population structure and mouse-virulence of strains from Gabon. PLoS Neglected Tropical Diseases, 4(11): e876. DOI: https://www.doi.org/10.1371/journal.pntd.0000876

Mikaeel FB, and Al-Saeed AT (2020). Molecular detection and seroprevalence of toxoplasmosis in free range local chickens (Gallus domesticus) in Duhok province, Iraq. Iraqi Journal of Veterinary Sciences, 34(2): 247-252. DOI: http://www.dx.doi.org/10.33899/ijvs.2019.125885.1173

Mohammed A, and Abdullah SH (2013). Diagnostic study of toxoplasmosis in domestic chickens in Sulaimani province. Al-Qadisiyah Journal of Veterinary Medicine and Science, 12(2): 63-69. DOI: https://www.doi.org/10.29079/vol12iss2art259

Montoya JG, and Liesenfeld O (2004). Toxoplasmosis. Lancet, 363: 1965-1976. DOI: https://www.doi.org/10.1016/s0140-

Mose JM, Kagira JM, Karanja SM, Ngotho M, Kamau DM, Njuguna AN, and Maina NW (2016). Detection of natural Toxoplasma gondii infection in chicken in Thika region of Kenya using nested polymerase chain reaction. BioMed Research International, pp. 1-5. DOI: https://www.doi.org/10.1155/2016/7589278

Mostafa NE, Abdel Hamed EF, Rahed HE, Mohamed SY, Abdelgawad M, and Elasbali AM (2018). The relationship between toxoplasmosis and different types of human tumors. Journal of Infection in Developing Countries, 12(2): 137-141. DOI: https://www.doi.org/10.3855/jidc.9672

Nazir MM, Akhtar M, Maqbool A, Waheed A, Sajid MA, Ali MA, Oneeb M, Alam MA, Ahmad AN, Nazir N et al. (2017). Antibody prevalence and risk factors for Toxoplasma gondii infection in women from Multan, Pakistan. Zoonoses and Public Health, 647: 537-542. DOI: https://www.doi.org/10.1111/zph.12336

Nardoni S, Rocchigiani G, Varvaro I, Altomonte I, Ceccherelli R, and Mancianti F (2019). Serological and molecular investigation on Toxoplasma gondii infection in wild birds. Pathogens, 8(2): 58. DOI: https://www.dx.doi.org/10.3390\%2Fpathogens8020058

Pan M, Lyu C, Zhao J, and Shen B (2017). Sixty years (1957-2017) of research on toxoplasmosis in China-an overview. Frontier in Microbiology, 8: 1825. DOI: https://www.doi.org/10.3389/fmicb.2017.01825

Pena HF, Gennari SM, Dubey JP, and Su C (2008). Population structure and mouse-virulence of Toxoplasma gondii in Brazil. International Journal of Parasitology, 38(5): 561-569. DOI: https://www.doi.org/10.1016/j.ijpara.2007.09.004

Pinard JA, Leslie NS, and Irvine PJ (2003). Maternal serologic screening for toxoplasmosis. Journal of Midwifery Womens Health, 48: 308-316. DOI: https:// www.doi.org/10.1016/s1526-9523(03)00279-4

Raafat MS, Khalil FAM, and Abu El Ezz NMT (2011). Cryptosporidiosis and toxoplasmosis in native quails of Egypt. Research Journal of Veterinary Sciences, 4: 30-36. DOI: https://www.dx.doi.org/10.3923/rjvs.2011.30.36

Rajendran C, Su C, and Dubey JP (2012). Molecular genotyping of Toxoplasma gondii from Central and South America revealed high diversity within and between populations. Infection, Genetics and Evolution, 12(2): 359-368. DOI: https://www.doi.org/10.1016/j.meegid.2011.12.010

Remington JS, McLeod R, Thulliez P, and Desmonts G (2006). Toxoplasmosis. In Infectious Diseases of Fetus and Newborn Infant, 6th ed.; Remington JS, Klein JO, Wilson CB, Baker CJ., Eds.; Elsevier-Saunders Company: Philadelphia, PA, USA. pp. 947-1091. DOI: http://www.dx.doi.org/10.1016/B0-72-160537-0/50033-5

Rong G, Zhou HL, Hou GY, Zhao JM, Xu TS, and Guan S (2014). Seroprevalence, risk factors and genotyping of Toxoplasma gondii in domestic geese (Anser domestica) in tropical China. Parasite Vector, 7: 459. DOI: https://www.doi.org/10.1186/s13071-014-0459-9

Ruiz A, and Frenkel JK (1980). Intermediate and transport hosts of Toxoplasma gondii in Costa Rica. American Journal of Tropical Medicine and Hygiene, 29: 1161-1166. DOI: https://www.doi.org/10.4269/ajtmh.1980.29.1161

Sato AP, Vaz FF, Konell AL, Koch MO, Ferreira RF, Sipinski EAB, and Dittrich RL (2020). Survey of Toxoplasma gondii, Neospora caninum and Sarcocystis neurona antibodies in wild red-tailed Amazon parrots (Amazona brasiliensis). Revista Brasileira de Parasitologia Veterinaria, 29(1): e017519. DOI: https://www.doi.org/10.1590/s1984-29612019107

Shokri A, Sharif M, Teshnizi SH, Sarvi S, Rahimi MT, Mizani A, Ahmadpour E, Montazeri M, and Daryani A (2017). Birds and poultries toxoplasmosis in Iran: A systematic review and meta-analysis. Asian Pacific Journal of Tropical Medicine, 10(7): 635-642. DOI: https://www.doi.org/10.1016/j.apjtm.2017.07.013

Shwab EK, Zhu XQ, Majumdar D, Pena HF, Gennari SM, Dubey JP, and Su C (2014). Geographical patterns of Toxoplasma gondii genetic diversity revealed by multilocus PCR-RFLP genotyping. Parasitology, 141(4): 453-461. DOI: https://www.doi.org/10.1017/s0031182013001844

Sibley LD, Khan A, Ajioka JW, and Rosenthal BM (2009). Genetic diversity of Toxoplasma gondii in animals and humans. Philosophical Transactions of the Royal Society B: Biological Sciences, 364: 2749-2761. DOI: https://www.dx.doi.org/10.1098\%2Frstb.2009.0087 
Simitch T, Bordjochki A, Savin Z, and Mikovitch Z (1965). Experimental oral infection of the pigeon with the vegetative form and the cystic form of Toxoplasma gondii. Bulletin de l'Académie Vétérinaire de France, 38(8): 333-336. Available at: https://pubmed.ncbi.nlm.nih.gov/5858567/

Simon A, Poulin MB, Rousseau AN, and Ogden NH (2013). Fate and transport of Toxoplasma gondii oocysts in seasonally snow covered watersheds: A conceptual framework from a melting snowpack to the Canadian Arctic Coasts. International Journal of Environmental Research and Public Health, 10(3): 994-1005. DOI: https://www.dx.doi.org/10.3390\%2Fijerph10030994

Sukthana Y (2006). Toxoplasmosis: beyond animals to humans. Trends in Parasitology, 22: 137-142. DOI: https://www.doi.org/10.1016/j.pt.2006.01.007

Swai ES, and Schoonman L (2009). Seroprevalence of Toxoplasma gondii infection amongst residents of Tanga District in north-east Tanzania, Tanzania. Journal of Health Research, 11(4): 205-209. DOI: https://www.doi.org/10.4314/thrb.v11i4.50178

Tenter AM, Heckeroth AR, and Weiss LM (2000). Toxoplasma gondii: From animals to humans. International Journal of Parasitology, 30: 1217-1258. DOI: https://www.doi.org/10.1016/s0020-7519(00)00124-7

Tilahun G, Tiao N, Ferreira L, Choudhary S, Oliveira S, Verma S, Kwok O, Molla B, Saville W, and Medhin G (2013). Prevalence of Toxoplasma gondii from free-range chickens (Gallus domesticus) from Addis Ababa, Ethiopia. Journal of Parasitology, 99: 740-741. DOI: https://www.doi.org/10.1645/12-25.1

Tsai YJ, Chung WC, Lei HH, and Wu YI (2006). Prevalence of antibodies to Toxoplasma gondii in pigeons (Columba livia) in Taiwan. Journal of Parasitology, 92(4): 871. DOI: https://www.doi.org/10.1645/ge-716r2.1

Wilking H, Thamm M, Stark K, Aebischer T, and Seeber F (2016). Prevalence, incidence estimations, and risk factors of Toxoplasma gondii infection in Germany: A representative, cross-sectional, serological study. Scientific Report, 6: 22551. DOI: https://www.doi.org/10.1038/srep22551

Yan C, Yue CL, Yuan ZG, He Y, Yin CC, Lin RQ, Dubey JP, and Zhua XQ (2009). Toxoplasma gondii infection in domestic ducks, free-range and caged chickens in southern China. Veterinary Parasitology, 165: 337-340. DOI: https://www.doi.org/10.1016/j.vetpar.2009.07.015

Zardi O, Giorgi G, Del Vecchio R, Venditti GE, and Drisaldi D (1967). Serological studies on Toxoplasma gondii infection in Amite risteto fauna of Lazio. Zoo Prophylaxis, 22: 223-237. Available at: https://core.ac.uk/download/pdf/59051783.pdf

Zhai CS, Jiang LX, and Shi ZL (1987). A survey on toxoplasmosis in human and domestic animals in the Nanjing area. Journal of Veterinary College, University of PLA, 7: 76-77. Available at: https://pubag.nal.usda.gov/download/37140/PDF

Zhang GN (1989). Epidemiological study on Toxoplasma infection in human beings and animals in Shandong Province. Zhonghua Liu Xing Bing Xue Za Zhi, 10: 30-33. Available at: https://pubmed.ncbi.nlm.nih.gov/2736611/

Zhang XX, Zhang NZ, Tian WP, Zhou DH, Xu YT, and Zhu XQ (2014). First report of Toxoplasma gondii seroprevalence in pet parrots in China. Vector Borne Zoonotic Diseases, 14(6): 394-398. DOI: https://www.doi.org/10.1089/vbz.2013.1522

Zhang XX, Zhao Q, Shi CW, Yang WT, Jiang YL, Wei ZT, Wang CF, and Yang GL (2016). Seroprevalence and associated risk factors of Toxoplasma gondii infection in the Korean, Manchu, Mongol and Han ethnic groups in eastern and northeastern China. Epidemiology and Infection, 144(9): 2018-2024. DOI: https:// www.doi.org/10.1017/s0950268815003337

Zia-Ali N, Fazaeli A, Khoramizadeh M, Ajzenberg D, Darde' M, and Keshavarz-Valian H (2007). Isolation and molecular characterization of Toxoplasma gondii strains from different hosts in Iran. Parasitological Research, 101(1): 111-115. DOI: https://www.doi.org/10.1007/s00436$\underline{007-0461-7}$

Zou Y, Nie LB, Zhang NZ, Zou FC, Zhu XQ, and Cong W (2017). First genetic characterization of Toxoplasma gondii infection in poultry meat intended for human consumption in eastern China. Infections, Genetics and Evolution, 55: 172-174. DOI: https://www.doi.org/10.1016/j.meegid.2017.08.022 